\section{Adsorption of Malachite Green by Clays and Allied Minerals}

THE malachite green stain test has long been used as a means of identifying kaolinite, dickite, and nacrite $e^{x}$. The quantitative aspect has not been dealt with adequately, and the method has never been applied with discrimination. Working on mineral separates obtained during the physical analyses of clays and soils, $\mathrm{I}$ have used staining quite extensively. Previously identified specimens of kaolinite, beidellite, etc., were used as controls, and the following represents the general colour reactions, after staining, drying, and mounting such separates.

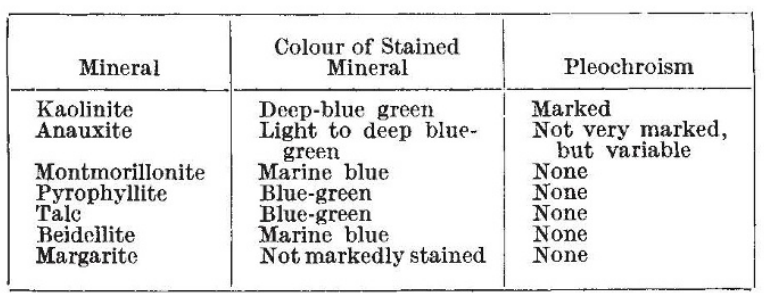

It was obvious after performing a few stain tests that these minerals adsorb different amounts of the dye, and take it with varying degrees of 'fastness'. For example, kaolinite is stained a deep blue-green colour in such a manner that no amount of washing with water, acid or alkali will remove the malachite green. The colour can be changed from blue-green in alkaline solution to a light red in acid conditions. It must also be noted that in the case of kaolinite and anauxite the birefringence is increased by staining from 1st order greys to 2nd order reds and purples.

Shand ${ }^{2}$, in a paper on the staining of etched sections of feldspathoidal rocks, remarks that long contact with the staining solution is unnecessary. My work on clays has confirmed this, and the following figures indicate that ten minutes contact with a 0.05 per cent aqueous malachite green solution is sufficient to remove more than 90 per cent of the dye from it. ${ }^{3}$

KAOLINITE-RICH WHITE KAOLIN

\begin{tabular}{|c|c|}
\hline Time of contact in min. & Adsorption of malachite green \\
\hline 1 & 85 \\
5 & 89 \\
10 & 92 \\
60 & 93 \\
120 & 93 \\
\hline
\end{tabular}

In this case the dye is never completely removed, whereas bentonitic clays and fuller's earths adsorb the malachite green from much stronger solutions. So far, no accurate diagnostic values of the amount of adsorption for the various minerals have been found. In fact, anauxite, for example, has a range of values depending probably upon its composition. With the exception of some of the kaolinites, few of the minerals used in this investigation were uncontaminated by other minerals. Fortunately, in every case the main impurity was quartz, which does not take the dye.

University of the Witwatersrand,

$$
\text { V. L. Bosazza. }
$$
Johannesburg.

${ }^{1}$ Ross, C. S., and Kerr, P. F., U.S. Geol. Surv. Prof. Paper (1931). ${ }^{2}$ Shand, S. J., Amer. Min., 24, 568-573 (1939).

${ }^{3}$ Holmes, A., "Petrographic Methods and Calculations", p. 275 (1930).

\section{Correlation between Egg-Carrying Setæ and Cement Glands in Decapod Crustacea}

IN the Decapod Crustacea the female possesses characteristically long non-plumose setæ on many of the abdominal, and in some cases certain of the posterior thoracic, appendages. It is to these hairs that the eggs are attached when the animal is in berry. It has been further shown by one of us ${ }^{1}$ that in Homarus vulgaris ducts from the cement glands, which occur exclusively in the pleopods of the female, pass into the interior of these specialized. setæ, "circumstantial evidence indicating that the secretion is discharged through the sides of these". In other words a direct correlation was postulated between the setæ and the glands, the former providing the surface of attachment of the eggs and the latter the necessary binding cement.

Confirmation of this view has now been provided as a result of work on Crangon vulgaris. As already briefly noted by Havinga ${ }^{2}$ and in more detail by Meyer ${ }^{3}$, mature females alternate between an egg. carrying condition when these setæ are present, and what may. be described as a 'neuter' condition when they are absent. Similar cyclical appearance of secondary female characters had already been described by Sollaud ${ }^{4}$ in other Caridae, in species of Leander and Palæmonetes. This has recently been confirmed by Callan ${ }^{5}$ in Leander xiphias and $L$. squilla. In $C$. vulgaris the female does not become mature until she attains a length of about $45 \mathrm{~mm}$. Previous to this the ovary is small, the egg-carrying setæ are represented by no more than vestiges while cement glands are absent. But prior to the moult when sexual maturity is attained, the ovary develops rapidly, and after the moult the egg-carrying setæ are fully developed. With them appear cement glands, one or more being associated with each spine into the cavity of which their ducts penetrate. The animal is then capable of spawning, copulation taking place immediately after this moult if males are present.

After the liberation of eggs the female moults into the 'neuter' condition; spines are then reduced, and cement glands absent. The ovary then increases in size, and in due course the animal moults into the egg-carrying condition with both spines and cement glands. This alteration of 'neuter' and egg-carrying conditions apparently continues throughout the remainder of the life of each female. A full account of this process will be published in due course by A. J. Lloyd.

This investigation reveals, therefore, that the eggcarrying setæ and the cement glands are in such intimate functional association that they may be regarded as a single secondary sexual character. The correlation between the condition of the ovary and the appearance of these structures provides further evidence in support of the previously expressed view ${ }^{1}$ that they are controlled by a hormone produced by the ovary. Moreover, Callan ${ }^{5}$ has recently demonstrated that the specialized setæ-and therefore also the glands-are not formed when Leander females are castrated with X-rays or when they are parasitized by Bopyrus.
Department of Zoology, The University,
A. J. Lloyd.

Bristol. August 14.

1 Yonge, Proc. Zool. Soc. Lond., A, 107, 499 (1938).

'Havinga, J. Con. Inter. Expl. Mer., 5, 57 (1930).

${ }^{3}$ Meyer, Zoo. Anz., 106, 145 (1934).

- Sollaud, Bull. Biol. France Belg., Supple., 5, 1 (1922).

- Callan, J. Exp. Biot., 17, 168 (1940). 